\title{
Perlakuan Air Panas pada Umbi Bawang Merah (Allium cepa var. ascalonicum) untuk Menekan Infeksi Virus di Lapangan
}

\author{
Hot Water Treatment on Shallot (Allium cepa var. ascalonicum) Tuber to Suppress \\ Viruses Infection in The Field
}

\author{
Heri Harti ${ }^{1,3 *}$, Sobir ${ }^{1,2}$, Suryo Wiyono ${ }^{1,3}$, dan Sri Hendrastuti Hidayat ${ }^{3}$
}

Diterima 12 Maret 2018/Disetujui 11 Juli 2018

\begin{abstract}
High infestation of viruses on shallot's bulb has been reported, although little is known on the effect of virus infection on shallot productivity. The use of virus-free bulbs is assumed to be the key factor to improve productivity. Hot water treatment of bulbs before planting is one of methodologies to eliminate virus from shallot bulbs. Therefore, research was conducted to study the effectiveness of hot water treatment methods of shallots bulbs to reduce virus infections in the field. Field experiment was conducted using split plot randomized block design with two factors. The first factor was the use of netting, i.e. growing shallot in netting house and in open field. The second factor was hot water treatment of shallot bulb at $45^{\circ} \mathrm{C}$ for 15, 30, and $45 \mathrm{~min}$ and without treatment. Observations were conducted on the incidence of virus infections, plant growth (number of tillers and plant height) and shallots productivity. Virus infection was confirmed using specific antibodies. Observation of disease symptom indicated that the use of netting house did not significantly suppress the incidence of virus diseases, while hot water treatment significantly reduced the incidence of virus diseases. Hot water treatment for 15, 30 and 45 minutes at $45{ }^{\circ} \mathrm{C}$ was able to suppress virus incidence in the field up to $54.98 \%, 56.77 \%$ and $64.35 \%$, respectively.
\end{abstract}

Key words: netting house, soaking time, viruses elimination, virus incidence

\begin{abstract}
ABSTRAK
Infestasi virus pada umbi bawang merah dilaporkan sangat tinggi, meskipun efek infeksi virus terhadap produktivitas bawang merah masih sedikit diketahui. Penggunaan umbi bebas virus diasumsikan menjadi salah satu faktor utama untuk meningkatkan produktivitas. Perlakuan air panas pada umbi sebelum tanam merupakan metode pilihan untuk mengeliminasi virus. Penelitian dilakukan dengan tujuan mempelajari keefektifan metode perlakuan air panas pada umbi bibit bawang merah terhadap infeksi virus di lapangan. Penelitian disusun menggunakan rancangan acak lengkap petak terbagi dengan dua faktor. Faktor pertama adalah perlakuan rumah kasa dengan dua taraf, yaitu penanaman dalam rumah kasa dan penanaman di lahan terbuka. Faktor kedua adalah perlakuan air panas suhu $45{ }^{\circ} \mathrm{C}$ dengan 4 taraf waktu perendaman, yaitu 15 menit, 30 menit, 45 menit dan kontrol (tanpa perlakuan). Pengamatan dilakukan terhadap insidensi penyakit, parameter pertumbuhan tanaman (jumlah anakan dan tinggi tanaman), dan produktivitas tanaman. Insidensi virus dikonfirmasi dengan deteksi menggunakan antibodi spesifik. Hasil pengamatan gejala menunjukkan bahwa perlakuan rumah kasa tidak berpengaruh nyata terhadap penekanan insidensi penyakit, sementara perlakuan pemanasan berpengaruh nyata terhadap penekanan insidensi penyakit. Waktu perendaman umbi selama 15, 30 dan 45 menit pada suhu $45^{\circ} \mathrm{C}$ dapat menekan insidensi penyakit virus dilapangan berturut-turut sebesar $54.98 \%, 56.77 \%$ dan $64.35 \%$.
\end{abstract}

Kata kunci: eliminasi virus, insidensi penyakit, rumah kasa, waktu perendaman

${ }^{1}$ Pusat Kajian Hortikultura Tropika, Institut Pertanian Bogor

Kampus IPB Baranangsiang Jalan Pajajaran Bogor 16144

${ }^{2}$ Departemen Agronomi dan Hortikultura, Fakultas Pertanian, Institut Pertanian Bogor

Jl. Meranti, Kampus IPB Darmaga, Bogor 16680

${ }^{3}$ Departemen Proteksi Tanaman, Fakultas Pertanian, Institut Pertanian Bogor

Jl. Kamper, Kampus IPB Darmaga, Bogor 16680

E-mail : heri.harti@yahoo.co.id (*Penulis korespondensi) 


\section{PENDAHULUAN}

Penggunaan benih sehat dan bebas patogen terutama virus adalah salah satu pendekatan yang efektif untuk peningkatan produksi dan produktivitas bawang merah. Beberapa jenis patogen, termasuk dari kelompok virus, dilaporkan dapat menginfeksi umbi bawang merah dan bersifat tular umbi. Dari beberapa penelitian dan publikasi diketahui bahwa virus yang paling banyak ditemukan dan menginfeksi pada tanaman bawang-bawangan adalah keompok Potyvirus, yaitu Onion yellow dwarf virus (OYDV), Shallot yellow stripe virus (SYSV) dan Leek yellow stripe virus (LYSV); kelompok Carlavirus, yaitu Shallot latent virus (SLV) dan Garlic common latent virus (GarCLV); dan kelompok Allexivirus, yaitu Shallot mite borne latent virus (MbLV), Garlic virus-B (Gar-V$\mathrm{B})$, Garlic virus- $C$ (Gar-V-C), Garlic virus-D (Gar-V-D) dan Garlic mosaic virus (GMV) (Diekmann, 1997; Shahraeen et al., 2008; Torrico et al., 2010; Bagi et al., 2012; Sevik dan Ackura, 2013; Swari et al., 2015; Smekalova, 2017). Virus yang menginfeksi bawang merah di Indonesia pertama kali dilaporkan oleh Sutarya et al. (1993) yaitu OYDV, LYSV, dan SLV dengan insidensi penyakit berkisar antara $29.75 \%$ sampai $76.33 \%$. Baru-baru ini Kadwati dan Hidayat (2015) melaporkan bahwa rata-rata infeksi virus pada bawang merah di lahan berkisar $11.2 \%$ sampai $14.3 \%$, sedangkan pada sampel umbi berkisar $11.2 \%$ sampai $13.3 \%$. Wulandari et al. (2015) juga mendeteksi infeksi OYDV, SLV, dan GarCLV yang sangat tinggi pada bawang merah, yaitu berturut-turut 97.78\%, 92.98\%, dan 92.18\%. Pengaruh infeksi virus terhadap kehilangan hasil bawang merah di Indonesia belum banyak diketahui. Infeksi OYDV dan SYSV dapat menurunkan bobot umbi bawang merah varietas Bima Curut dan Filipina sebesar 4.65\% (Gunaeni et al. (2011a). Lebih lanjut, Bagi et al. (2012) melaporkan bahwa kehilangan hasil yang disebabkan infeksi OYDV dapat menurunkan bobot umbi sebesar $21.5 \%$.

Pada umumnya petani di Indonesia menggununakan umbi (cara vegeratif) untuk memperbanyak bawang merah, sehingga virus dapat berkembang dan terakumulasi pada umbi. Umbi dapat berperan sebagai inokulum bagi tanaman sehat lainnya, apabila umbi yang mengandung virus digunakan sebagai benih untuk pertanaman berikutnya. Jika virus sudah menginfeksi jaringan tanaman bawang merah, maka akan terus berkembang sehingga dapat memengaruhi kualitas bahan tanaman yang dihasilkan. Penggunaan benih bebas virus merupakan salah satu usaha yang dapat dilakukan untuk mengembalikan potensi genetik bawang merah akibat infeksi virus. Benih bebas virus dapat diperoleh dengan beberapa strategi diantaranya adalah melakukan eliminasi virus pada umbi. Beberapa metode eliminasi virus pada berbagai jenis tanaman dilaporkan telah berhasil dilakukan diantaranya teknik kultur jaringan (kultur meristem), terapi pemanasan, dan penggunaan antiviral sintetik (Panattoni et al., 2013). Menurut Aqlima et al. (2017), efisiensi eliminasi virus menggunakan kultur meristem tip dapat ditingkatkan dengan cara mengombinasikan kultur meristem tip dengan metode lainnya, agar dapat mengeliminasi OYDV secara efektif pada tanaman yang terinfeksi.

Wulandari (2016) berhasil melakukan eliminasi OYDV pada umbi bawang merah dengan perlakuan air panas $45{ }^{\circ} \mathrm{C}$ selama 15 menit pada skala percobaan di rumah kaca. Sulistio et al. (2015) melaporkan bahwa kombinasi perlakuan panas dalam inkubator suhu $37{ }^{\circ} \mathrm{C}$ selama 4 minggu dan perlakuan panas dalam penangas air pada $45^{\circ} \mathrm{C}$ selama 60 menit pada umbi bawang merah kultivar Biru Lancor secara in vitro dapat menekan insidensi SLV hingga 100\%. Untuk itu perlu dilakukan verifikasi efisiensi upaya eliminasi virus dari umbi pada skala lapangan. Penelitian ini bertujuan untuk mengevaluasi keefektifan metode perlakuan air panas pada umbi bibit bawang merah untuk menghambat perkembangan infeksi virus di lapangan.

\section{BAHAN DAN METODE}

Kegiatan penelitian berlangsung sejak bulan Februari sampai September 2016. Pengujian lapangan dilaksanakan di lahan petani, di Kecamatan Kersana, Kabupaten Brebes. Perlakuan air panas untuk umbi sebelum tanam dilaksanakan di Laboratorium Pusat Kajian Hortikultura Tropika; sedangkan deteksi virus dilaksanakan di Laboratorium Virologi Tumbuhan Departemen Proteksi Tanaman IPB. 


\section{Persiapan Tanam}

Umbi bawang merah yang digunakan adalah kultivar Bima Brebes yang siap tanam (umur simpan \pm 2 bulan). Perlakuam air panas terhadap umbi dilakukan dengan cara membungkus umbi bawang merah dengan waring buah (kantung jala plastik), kemudian umbi tersebut direndam dalam penangas air (waterbath) pada suhu $45{ }^{\circ} \mathrm{C}$ dengan beberapa taraf perlakuan lama perendaman $(15,30$ dan 45 menit). Sebagai pembanding (kontrol) digunakan umbi bawang merah tanpa perlakuan air panas. Setelah itu, umbi yang sudah diberi perlakuan air panas diletakkan di atas kertas untuk dikeringanginkan dan siap ditanam di lapangan.

\section{Penanaman Umbi}

Penelitian lapangan disusun menggunakan rancangan acak lengkap petak terbagi dengan dua faktor. Faktor pertama adalah perlakuan rumah kasa dengan dua taraf, yaitu penanaman dalam rumah kasa dan penanaman di lahan terbuka. Faktor kedua adalah perlakuan air panas suhu $45{ }^{0} \mathrm{C}$ dengan 4 taraf waktu perendaman yaitu, 15 menit, 30 menit, 45 menit dan kontrol (tanpa perlakuan). Rumah kasa dibangun menggunakan kain kasa 400 mesh, rangka bambu setinggi $3 \mathrm{~m}$ dari permukaan tanah, dan dilengkapi pintu ganda. Teknik budi daya bawang merah merujuk pada panduan penanaman bawang merah yang ditetapkan oleh Direktorat Sayuran dan Tanaman Obat, Dirjen Hortikultura, Kementerian Pertanian.

\section{Pengambilan Sampel Tanaman dan Deteksi Virus}

Pengambilan sampel daun dari lapangan dilakukan ketika tanaman berumur 30 hari setelah tanam. Sampel daun yang telah diambil disimpan dalam lemari pendingin $\left(-80{ }^{\circ} \mathrm{C}\right)$ di Laboratorium Virologi Tumbuhan IPB sampai saatnya digunakan. Metode deteksi virus yang digunakan adalah dot immunobinding assay (DIBA) berdasarkan metode Asniwita et al. (2012) dengan antibodi spesifik GarCLV, SLV, OYDV, dan SYSV.

Tahap pertama pengujian adalah menggerus sampel daun. Masing-masing sampel sebanyak $0.1 \mathrm{~g}$ digerus dalam tris buffer saline (TBS) dengan perbandingan 1:10 (b:v) (TBS: Tris- $\mathrm{HCl} 0.02 \mathrm{M}$ dan $\mathrm{NaCl} 0.15 \mathrm{M}, \mathrm{pH}$
7.5) sampai didapatkan cairan perasan tanaman. Setelah itu, $2 \mu \mathrm{l}$ cairan perasan tanaman diteteskan ke membran nitroselulosa dan dikeringkan. Selanjutnya membran direndam di dalam $2 \%$ larutan blocking skim milk $(10 \mathrm{ml}$ TBS yang mengandung Triton X-100 + 2\% skim milk). Membran kemudian diinkubasi pada suhu ruang sambil digoyang dengan kecepatan 50 rpm selama 1 jam menggunakan EYELA multi shaker MMS. Setelah \pm 1 jam (tetesan warna hijau pada membran telah hilang), kemudian membran dicuci sebanyak 5 kali dengan $\mathrm{dH}_{2} \mathrm{O}$, tiap pencucian berlangsung 5 menit sambil digoyang dengan kecepatan 100 $\mathrm{rpm}$. Selajunya membran direndam dalam TBS yang mengandung antibodi pertama (IgG) ditambah $2 \%$ skim milk, kemudian membran diinkubasi pada suhu $4{ }^{0} \mathrm{C}$ selama 1 malam. Konsentrasi antibodi yang digunakan adalah 1:1000 untuk GarCLV, SLV, dan SYSV, dan 1:500 untuk OYDV (DSMZ, GmbH-German). Setelah direndam dalam antibodi pertama, membran dicuci dengan Tween $0.05 \%$ dalam TBS (TBST) sebanyak 5 kali, tiap pencucian dilakukan selama 5 menit. Setelah itu, membran direndam kembali dalam TBS yang mengandung konjugat (antibodi kedua) ditambah $2 \%$ skim milk dengan perbandingan sesuai dengan konsentrasi yang digunakan pada saat perendaman dengan antibodi pertama. Membran kemudian diinkubasi sambil digoyang dengan kecepatan 50 rpm selama 60 menit. Setelah direndam dan diinkubasi selama $1 \mathrm{jam}$, membran dicuci kembali dengan TBST dan direndam dalam larutan penyangga Alcaline phosphatase (Tris- $\mathrm{HCl} 0.1 \mathrm{M}, \mathrm{NaCl}$ $0.1 \mathrm{M}, \mathrm{MgCl}_{2} 5 \mathrm{mM}$, dan $10 \mathrm{ml}$ air) yang mengandung nitro blue tetrazolium (NBT) dan bromo chloro indolil phosphate (BCIP) (1 tablet NBT/BCIP:10 ml buffer AP) selama 5 menit. Terjadinya perubahan warna putih menjadi ungu pada membran nitroselulosa yang telah ditetesi cairan tanaman menyatakan bahwa reaksi DIBA positif. Untuk menghentikan reaksi dilakukan dengan cara merendam membran dalam $\mathrm{dH}_{2} \mathrm{O}$.

\section{Pengamatan dan Analisis Data}

Data yang diambil dari percobaan lapangan terdiri atas insidensi penyakit, pertumbuhan tanaman (jumlah daun, tinggi tanaman, jumlah anakan) dan data produksi (jumlah umbi per rumpun, diameter umbi, dan 
bobot umbi per rumpun). Insidensi penyakit dihitung dengan rumus:

$$
\begin{gathered}
\text { Insidensi penyakit }= \\
\frac{\text { Jumlah sampel terinfeksi }}{\text { Jumlah sampel yang diamati }} \times 100
\end{gathered}
$$

Jumlah tanaman terinfeksi ditetapkan berdasarkan hasil deteksi virus menggunakan metode DIBA. Analisis sidik ragam data dilakukan menggunakan program Statistical Tool for Agricultural Research (STAR) versi 2.0.1 (IRRI, 2013).

\section{HASIL DAN PEMBAHASAN}

\section{Kondisi Umum}

Kecamatan Kersana, Kabupaten Brebes merupakan dataran rendah dengan ketinggian 9 meter di atas permukaan laut (m dpl). Suhu rata-rata di lahan percobaan bulan Juli sampai September 2016 mencapai $35{ }^{0} \mathrm{C}$ dengan kisaran $29{ }^{\circ} \mathrm{C}$ sampai dengan $41{ }^{0} \mathrm{C}$; kelembapan rata-rata mencapai $71 \%$ dengan kisaran 67\% sampai dengan 73\%. Lahan percobaan dikelilingi pertanaman bawang merah komersial, karena lokasi tersebut berada di sentra produksi bawang merah di Jawa Tengah. Lahan percobaan berupa bedengan dengan lebar $1.2 \mathrm{~m}$ dan dikeliling parit/selokan sebagai sarana irigasi. Gangguan utama pada tanaman selama penelitian berlangsung adalah serangan ulat grayak (Spodoptera exigua) dan penyakit "moler" (Fusarium sp). Petani melakukan upaya pengendalian terhadap organisme penggangu tanaman tersebut melalui aplikasi pestisida yang sangat intensif.

\section{Gejala Infeksi Virus di Lapangan}

Gejala infeksi virus di lapangan muncul 2 minggu setelah tanam (MST), yaitu daun pipih bergaris kuning pucat ditengah, garisgaris hijau, garis-garis kuning dan daun berkerut. Gejala tersebut masih tampak jelas sampai 4 MST (Gambar 1). Gejala yang sama dilaporkan oleh Kadwati dan Hidayat (2015) pada tanaman bawang merah di Brebes. Gejala yang paling banyak ditemukan adalah daun pipih bergaris kuning pucat di tengah, sedangkan gejala yang paling sedikit ditemukan adalah daun bergaris kuning. Gejala yang beragam muncul seiring dengan meningkatnya umur tanaman. Selain gejala tunggal, juga ditemukan campuran dari berbagai gejala. Gejala mosaik kuning disertai dengan garis vertikal yang bersambung dan atau terputusputus, khlorosis, daun bergaris hijau dilaporkan sebelumnya oleh Gunaeni et al. (2011b).

\section{Pengaruh Perlakuan Air Panas dan Rumah kasa terhadap Infeksi Virus di Lapangan}

Perlakuan rumah kasa menunjukkan hasil analisis statistika yang tidak berpengaruh nyata terhadap penekanan insidensi penyakit di lapangan. Insidensi penyakit berbeda nyata pada perlakuan lama pemanasan mulai 2 MST sampai 5 MST (Gambar 2). Gejala mulai muncul 2 MST pada semua perlakuan, artinya perlakuan air panas tidak memundurkan waktu infeksi.
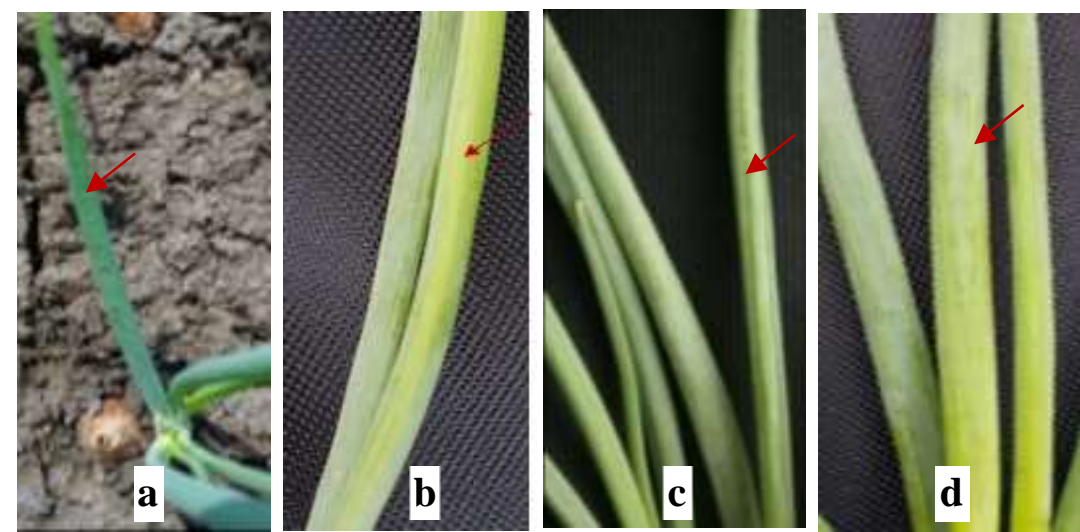

Gambar 1. Gejala infeksi virus pada tanaman bawang merah di Brebes pada 4 MST (a) daun berkerut; (b) daun pipih bergaris kuning pucat di tengah; (c) daun bergaris hijau; (d) daun bergaris kuning 
Berdasarkan pengamatan pada 5 MST perlakuan air panas selama 45 menit, menunjukkan insidensi penyakit yang paling rendah, yaitu sebesar $35.65 \%$ diikuti oleh lama pemanasan 30 menit dan 15 menit dengan insidensi penyakit berturut-turut $44.23 \%$ dan $45.02 \%$, sementara pada tanaman tanpa perlakuan mencapai $100 \%$. Data insidensi penyakit tersebut membuktikan bahwa perlakuan air panas pada umbi bawang merah suhu $45{ }^{\circ} \mathrm{C}$ dengam lama perendaman 15,30 , dan 45 menit dapat mengurangi atau menekan infeksi virus di lapangan berturut-turut sebesar 54.98, 56.77, dan $64.35 \%$.

Hasil analisis perlakuan rumah kasa dan lamanya perendaman terhadap insidensi penyakit virus di lapangan menunjukkan tidak ada interaksi (Tabel 1). Hal ini terlihat dengan nilai $\mathrm{F}$ hitung (mulai 2 MST sampai 5 MST) lebih dari 0.05 .

Insidensi penyakit pada perlakuan rumah kasa dan lahan terbuka tidak berbeda nyata. Hal tersebut mengindikasikan rendahnya peran kutudaun sebagai vektor virus pada pertanaman bawang merah. Penggunaan pestisida yang sangat intensif dapat menyebabkan populasi serangga rendah sehingga kejadian penularan virus melalui kutudaun juga rendah. Selain itu, infeksi virus yang bersifat sistemik dan tular umbi akan menyebabkan insidensi penyakit yang tinggi sejak awal pertumbuhan tanaman.

\section{Deteksi Virus dari Sampel Daun}

Infeksi virus pada tanaman bergejala dikonfirmasi dengan deteksi menggunakan metode DIBA. Sebanyak tiga jenis virus berhasil dideteksi, yaitu, SYSV dari kelompok Potyvirus, GarCLV dan SLV dari kelompok Carlavirus. Dari hasil deteksi diketahui bahwa perlakuan air panas pada suhu $45{ }^{\circ} \mathrm{C}$ dengan waktu perendaman selama 45, 30, dan 15 menit dapat mengurangi atau menekan insidensi virus (Tabel 2). Hasil deteksi ini mengkonfirmasi hasil pengamatan gejala di lapangan, yaitu perlakuan lama pemanasan 45 menit menunjukkan insidensi virus paling rendah baik pada perlakuan rumah kasa maupun lahan terbuka. Pada tanaman di rumah kasa, lama pemanasan 45 menit dapat menekan infeksi SYSV, GarCLV, dan SLV berturut-turut sebesar 61.2, 61.1, dan 55.7\%. Sementara pada tanaman di lahan terbuka, lama pemanasan 45 menit dapat menekan infeksi SYSV, GarCLV, dan SLV berturut-turut sebesar 61.1, 56.6, dan $61.1 \%$.

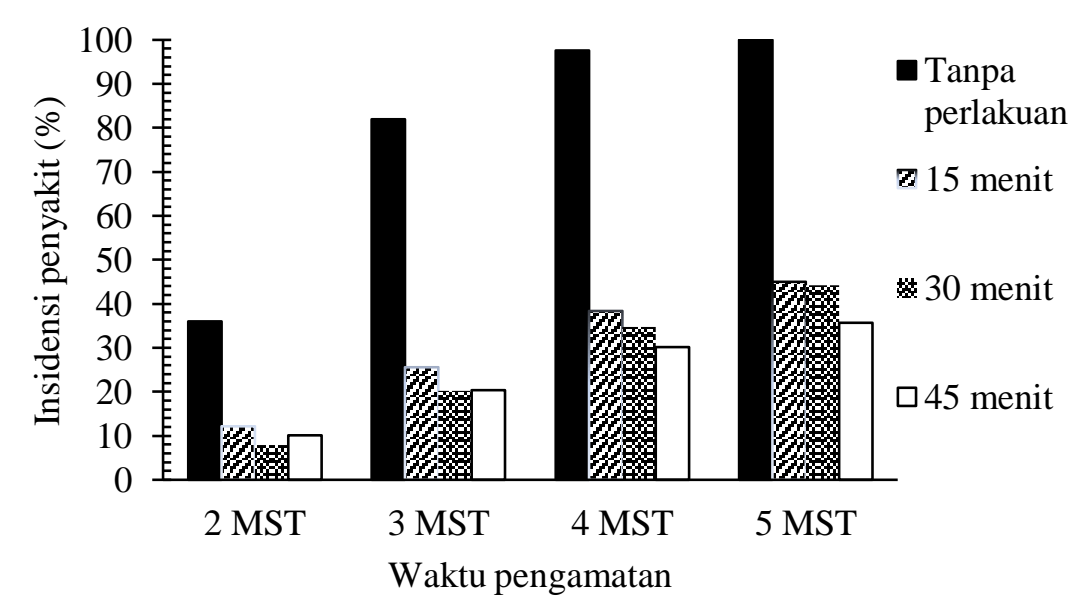

Gambar 2. Pengaruh perlakuan lama pemanasan pada suhu $45{ }^{\circ} \mathrm{C}$ terhadap persentase insidensi penyakit

Tabel 1. Nilai interaksi perlakuan kasa dan lama perendaman terhadap persentase insidensi penyakit berdasarkan gejala pada bawang merah

\begin{tabular}{cc}
\hline Waktu Pengamatan & Nilai F Hitung \\
\hline 2 MST & 0.32 \\
3 MST & 0.78 \\
4 MST & 0.40 \\
5 MST & 0.18 \\
\hline
\end{tabular}


Tabel 2. Pengaruh perlakuan lama pemanasan pada suhu $45{ }^{\circ} \mathrm{C}$ dan rumah kasa terhadap persentase insidensi infeksi virus pada bawang merah berdasarkan hasil DIBA

\begin{tabular}{lcccc}
\hline \multirow{2}{*}{ Perlakuan } & \multicolumn{4}{c}{ Insidensi Infeksi Virus (\%) } \\
\cline { 2 - 5 } & OYDV & GarCLV & SYSV & SLV \\
\hline Rumah Kasa & 0 & $94.4(17 / 18)$ & $100.0(18 / 18)$ & $88.9(16 / 18)$ \\
Kontrol & 0 & $44.4(8 / 18)$ & $77.7(14 / 18)$ & $55.5(10 / 18)$ \\
15 menit & 0 & $44.4(8 / 18)$ & $50.0(9 / 18)$ & $50.0(9 / 18)$ \\
30 menit & 0 & $33.3(6 / 18)$ & $38.8(7 / 18)$ & $33.3(6 / 18)$ \\
45 menit & 0 & $88.9(16 / 18)$ & $83.3(15 / 18)$ & $94.4(17 / 18)$ \\
Lahan Terbuka & 0 & $44.4(8 / 18)$ & $50.0(9 / 18)$ & $50.0(9 / 18)$ \\
Kontrol & 0 & $33.3(6 / 18)$ & $44.4(8 / 18)$ & $44.4(8 / 18)$ \\
15 menit & 0 & $27.7(8 / 18)$ & $27 / 7(5 / 18)$ & $33.3(6 / 18)$ \\
30 menit & & & & \\
45 menit & & &
\end{tabular}

Hasil penelitian menunjukkan bahwa perlakuan air panas suhu $45{ }^{\circ} \mathrm{C}$ dapat menekan infeksi virus. Hal ini sesuai dengan hasil penelitian Sulistio et al. (2015), kombinasi perlakuan panas suhu $37{ }^{\circ} \mathrm{C}$ dalam inkubator selama 4 minggu dan perlakuan panas dalam penangas air suhu $45^{\circ} \mathrm{C}$ selama 60 menit pada umbi bawang merah kultivar Biru Lancor dapat menekan insidensi SLV hingga $100 \%$. Sementara itu, perlakuan air panas pada umbi bawang merah suhu $45{ }^{0} \mathrm{C}$ selama 15 menit yang dikombinasikan dengan kultur jaringan efektif mengeliminasi Potyvirus dan Carlavirus sampai $100 \%$ pada kultivar Bima Curut (Wulandari, 2016). Hasil penelitian Nasution et al. (2017) menunjukkan bahwa perlakuan termoterapi pada suhu $33{ }^{\circ} \mathrm{C}$ pada bawang putih mampu menekan OYDV sebesar 60\%. Perlakuan air panas dapat menurunkan insidensi penyakit di lapangan karena adanya mekanisme penghambatan replikasi dan translokasi virus di dalam jaringan tanaman. Hadidi et al. (1998) menyatakan bahwa perlakuan panas dapat mengganggu kerja movement protein dan protein selubung virus yang mempunyai peran penting dalam penyebaran virus di dalam jaringan tanaman. Tanaman yang diberi perlakuan panas dapat menurunkan sintesis movement protein (MP), coat protein $(\mathrm{CP})$ virus dengan menghambat sintesis RNA virus (Bhojwani dan Dantu, 2013).

Tabel 3. Pengaruh perlakuan lama pemanasan pada suhu $45^{\circ} \mathrm{C}$ terhadap pertumbuhan vegetatif tanaman

\begin{tabular}{ccccccc}
\hline Lama Pemanasan Suhu & \multicolumn{3}{c}{4 MST } & \multicolumn{3}{c}{6 MST } \\
\cline { 2 - 6 } $45{ }^{\circ} \mathrm{C}$ & $\begin{array}{c}\text { Tinggi } \\
\text { Tanaman } \\
(\mathrm{cm})\end{array}$ & $\begin{array}{c}\text { Jumlah } \\
\text { Daun }\end{array}$ & $\begin{array}{c}\text { Jumlah } \\
\text { Anakan }\end{array}$ & $\begin{array}{c}\text { Tinggi } \\
\text { Tanaman } \\
(\mathrm{cm})\end{array}$ & $\begin{array}{c}\text { Jumlah } \\
\text { Daun }\end{array}$ & $\begin{array}{c}\text { Jumlah } \\
\text { Anakan }\end{array}$ \\
\hline Tanpa perlakuan & $29.58 \mathrm{a}$ & $29.58 \mathrm{a}$ & $6.13 \mathrm{~b}$ & $32.12 \mathrm{a}$ & $22.67 \mathrm{a}$ & $6.71 \mathrm{a}$ \\
15 menit & $29.08 \mathrm{a}$ & $19.50 \mathrm{a}$ & $5.71 \mathrm{a}$ & $31.65 \mathrm{a}$ & $22.58 \mathrm{a}$ & $6.01 \mathrm{~b}$ \\
30 menit & $28.18 \mathrm{a}$ & $19.50 \mathrm{a}$ & $5.43 \mathrm{a}$ & $30.65 \mathrm{a}$ & $22.85 \mathrm{a}$ & $5.78 \mathrm{~b}$ \\
45 menit & $28.38 \mathrm{a}$ & $18.94 \mathrm{a}$ & $5.50 \mathrm{a}$ & $30.69 \mathrm{a}$ & $21.90 \mathrm{a}$ & $5.89 \mathrm{~b}$ \\
\hline
\end{tabular}

Keterangan: Angka-angka yang diikuti oleh huruf yang berbeda pada kolom yang sama adalah berbeda nyata pada uji DMRT taraf $5 \%$.

Tabel 4. Produksi tanaman bawang merah pada perlakuan lama pemanasan umbi

\begin{tabular}{cccc}
\hline Lama Pemanasan & $\begin{array}{c}\text { Jumlah Umbi per } \\
\text { Rumpun }\end{array}$ & $\begin{array}{c}\text { Bobot Umbi per } \\
\text { Rumpun }(\mathrm{g})\end{array}$ & Diameter Umbi (mm) \\
\hline Kontrol & $6.83 \mathrm{~b}$ & $22.60 \mathrm{c}$ & $14.41 \mathrm{c}$ \\
15 menit & $8.34 \mathrm{a}$ & $37.71 \mathrm{a}$ & $19.53 \mathrm{a}$ \\
30 menit & $8.44 \mathrm{a}$ & $35.13 \mathrm{a}$ & $18.67 \mathrm{~b}$ \\
45 menit & $8.43 \mathrm{a}$ & $34.17 \mathrm{~b}$ & $18.33 \mathrm{~b}$ \\
\hline
\end{tabular}

Keterangan: Angka-angka yang diikuti oleh huruf yang berbeda pada kolom yang sama adalah berbeda nyata pada uji DMRT taraf $5 \%$ 
Hasil analisis statistika menunjukkan bahwa waktu perendaman umbi tidak berpengaruh nyata terhadap pertumbuhan vegetatif tanaman (Tabel 3), akan tetapi berpengaruh nyata terhadap produksi (bobot umbi per rumpun dan diameter umbi (Tabel 4). Perlakuan air panas $45{ }^{\circ} \mathrm{C}$ selama 15 menit menghasilkan diameter umbi dan bobot umbi per rumpun lebih baik dibandingkan waktu perendaman 30 dan 45 menit. Perlakuan air panas pada suhu $45{ }^{\circ} \mathrm{C}$ tidak merusak jaringan tanaman, sehingga tidak memengaruhi pertumbuhan vegetatif tanaman, akan tetapi dapat menekan insidensi virus. Berdasarkan hasil penelitian Sutrawati et al. (2010) diketahui bahwa perlakuan perendaman air panas pada stek daun nenas dengan suhu $58{ }^{\circ} \mathrm{C}$, 40 menit dapat menginaktifkan Pineapple mealybug wilt-associated virus yang menginfeksi tanaman nanas dan daya tumbuh stek daun serta batang nanas masih dapat tetap dipertahankan (60\%). Menurut Damayanti et al. (2010), kisaran suhu antara $55^{\circ} \mathrm{C}$ sampai 60 ${ }^{0} \mathrm{C}$ merupakan titik inaktivasi untuk Sugarcane streak mosaic virus (SCSMV). Meskipun perlakuan air panas tidak sepenuhnya menghilangkan SCSMV, namun perlakuan air panas suhu $53{ }^{\circ} \mathrm{C}, 10$ menit menekan keparahan penyakit secara drastis dan tetap menjaga viabilitas tanaman $100 \%$. Menurut Balamuralikrishnan et al. (2003), panas juga bisa menyebabkan inaktivasi virus pada awal fase yang mengakibatkan penurunan titer Sugarcane mosaic virus (SCMV). Perlakuan air panas pada bahan tanaman dapat digunakan untuk eliminasi dan menekan infeksi patogen dengam syarat toleransi patogen terhadap panas lebih rendah dibandingkan toleransi bahan tanaman. Jika syarat tersebut dapat terpenuhi, maka interval suhu untuk perlakuan air panas yang dapat mengeliminasi dan menekan patogen tetapi tidak berpengaruh negatif terhadap viabilitas bahan tanaman. Menurut Forsberg (2001) interval atau kisaran suhu yang dapat mengeliminasi dan menekan patogen serta tidak berpenagaruh negatif terhadap viabilitas bahan tanaman disebut "treatment window". Dalam penelitian ini, perlakuan air panas pada umbi bawang merah suho $45{ }^{\circ} \mathrm{C}$ dengan interval waktu 15 sampai dengan 45 menit memenuhi syarat dan direkomendasikan sebagai salah satu metode untuk penekanan infeksi virus pada bawang merah tanpa mempengaruhi viabitas dan pertumbuhan vegetatif bawang merah.

Perlakuan air panas $45{ }^{\circ} \mathrm{C}$ selama 15,30 dan 45 menit menghasilkan diameter umbi dan bobot umbi per rumpun lebih baik dibandingkan kontrol (tanpa perlakuan). Perlakuan air panas pada suhu $45{ }^{\circ} \mathrm{C}$ tidak merusak jaringan tanaman, sehingga tidak memengaruhi pertumbuhan vegetatif tanaman, akan tetapi dapat menekan insidensi virus. Diekmann (1997) menyatakan bahwa serangan virus pada bawang merah menyebabkan pertumbuhan tanaman terhambat dan bahkan menyebabkan tanaman menjadi kerdil, sehingga akan mengakibatkan ukuran umbi lebih kecil dibandingkan umbi dari tanaman normal. Infeksi virus yang berkurang secara nyata dengan perlakuan air panas suhu $45{ }^{\circ} \mathrm{C}$ berpengaruh pada peningkatan produksi tanaman secara nyata. Dengan asumsi populasi tanaman per ha sebanyak 266667 rumpun, maka dengan memberi perlakuan air panas 45 ${ }^{0} \mathrm{C}$ selama 15,30 dan 45 menit akan menghasil produksi 10.05, 9.11 dan 9.37 ton $\mathrm{ha}^{-1}$ dibandingkan kontrol hanya 5.88 ton ha ${ }^{-1}$.

\section{KESIMPULAN}

Perlakuan pemanasan umbi bawang merah pada suhu $45{ }^{\circ} \mathrm{C}$ mampu menekan infeksi virus dengan perlakuan yang paling efektif adalah lama pemanasan 45 menit, yaitu menekan insidensi penyakit sebanyak $64.35 \%$. Perlakuan pemanasan juga berpengaruh meningkatkan produksi tanaman bawang merah sebesar $55-71 \%$.

\section{DAFTAR PUSTAKA}

Aqlima, B.S. Purwoko, S.H. Hidayat, D. Dinarti. 2017. Eliminasi onion yellow dwarf virus melalui kultur meristem tip pada bawang merah (Allium ascalonicum L.). J. Hort. Indonesia. 8(1): 22-30.

Asniwita, S.H. Hidayat, G. Suastika, S. Sujiprihati, S. Susanto, I. Hayati. 2012. Eksplorasi isolat lemah Chili veinal mottle Potyvirus pada pertanaman cabai di Jambi, Sumatera Barat, dan Jawa Barat. J. Hort. 22(2):181-186. 
Bagi, F., V. Stojsin, D. Budakov, M.A.E. Salma, J.G. Varga. 2012. Effect of Onnion yellow dwarf virus (OYDV) on yield components of fall garlic (Allium sativum L.) in Serbia. Afr. J. Agric. Res. 7(15): 2386-2390.

Balamuralikhrishnan, M., S. Doraisamy, T. Ganapathy, R.Viswanathan. 2003 Impact of serial thermotherapy on Sugarcane mosaic virus titre and regeneration in sugarcane. Arch Phytopathol and Plant Protect. 36:173178.

Bhojwani, S.S., P.K. Dantu. 2013. Production of virus-free plants. In: Bhojwani SS, P.K. Dantu, editor. Plant Tissue Culture: an Introduction Text. New Delhi (ID). Springer India. p. 227-243. doi 10.1007/978-81-322-1026-9_16.

Diekmann, M. 1997. FAO/IPGRI Technical Guidelines for the Safe Movement of Germplasm. No. 18. Allium spp. Roma (IT): Food and Agriculture Organization of the United Nations. Rome: Rome/International Plant Genetik Resources Institute.

Damayanti, T.A., L.K. Putra, Giyanto. 2010. Hot water treatment of cutting cane infected with Sugarcane streak mosaic virus (SCSMV). J. ISSAAS. 16(2):1725 .

Forsberg, G. 2001. Heat sanitation of cereal seeds with a new, efficient, cheap and environmentally friendly method. In: A.J. Biddle (ed). Seed Treatment, Challenges and Opportunities. Proceedings from Symposium No. 76 of the British Crop Protection Council BCPC, Farnham. pp. 69-72.

Gunaeni, N., M.L. Ratnawati, A.S. Duriat. 2001a. Hubungan penampilan sehat dari benih bawang merah terhadap pertumbuhan dan hasil panen. Dalam Purwanta A., Sitepu D, Mustika I, Mulyana K, Sudjono MS, Hidayat SH, Supriadi, Widodo, dan Dumalang YE. (Eds.). Prosiding Kongres Nasional XVI dan Seminar Ilmiah Perhimpunan
Fitopatologi Indonesia. Bogor, 22-24 Agustus 2001. Hlm. 231-235.

Gunaeni, N., A.W. Wulandari, A.S. Duriat, A. Muharam. 2011b. Insiden penyakit tular umbi pada tiga belas varietas bawang merah asal Jawa Barat dan Jawa Tengah. J. Hort. 21(2): 164-172.

Guswanto, R., N. Gunaeni, A.S. Duriat. 2009. Seleksi tanaman tomat berdasarkan ketahanan pasif dan aktif terhadap CMV. J. Hort. 19(4): 377-385.

Hadidi, A., R.K. Khetarpal, H. Koganezawa. 1998. Plant Virus Diseases Control. USA: APS.

Kadwati, S.H. Hidayat. 2015. Deteksi virus utama bawang merah dan bawang putih dari daerah Jawa Barat dan Jawa Tengah. J. Fitopatol. Indonesia. 11(4): 121-127.

Nasution, S.S., D. Dinarti, S.H. Hidayat. 2017. Pengaruh Elektroterapi dan Termoterapi secara in Vitro terhadap Eliminasi Onion yellow dwarf virus. J. Fitopatol. Indonesia. 13(6): 199-206.

Panattoni, A., A. Luvisi, E. Triolo. 2013. Elimination of viruses in plants: twenty years of progress (review). Spanish Journal of Agricultural Research. 11(1): 173-188.

Sevik, M.A., C. Akcura. 2013. Viruses occuring in onion crop in Amasya province, the major onion producing region in Turkey. Indian J. Virol. 24(1): 78-81.

Shahraeen, N., D.E. Lesemann, T. Gholbi. 2008. Survey for viruses infecting onion, garlic, and leek crops in Iran. Eppo Bull. 38: 131-135.

Smékalová, K., H. Stavělíková, K. Dušek. 2017. Distribution of viruses in the shallot germplasm collection of the Czech Republic - Short Communication. Hort. Sci. 44(1): 49-52. 
Sulistio, M., E. Sulistyaningsih, S. Subandiyah. 2015. Elimination of shallot bulb viruses through heat treatment. Int. J. Biotech. 20(2): 133-140.

Sutarya, R., V. Vreden, E. Korlina, N. Gunaeni, A.S. Duriat. 1993. Survei virus bawang merah pada beberapa lokasi di Kabupaten Brebes, Jawa Tengah. Bull. Penel. Hort. 26(1): 97-106.

Sutrawati, M., G. Suastika, Sobir. 2010. Eliminasi Pineapple mealy bug wiltassociated-virus (PMWaV) dari tanaman nanas dengan hot water treatment. JIPI. 12(1):19-25.

Swari, F.S.P., S. Subandiyah, S. Hartono. 2015. Deteksi dan identifikasi virus-virus yang menginfeksi bawang merah di Kabupaten Bantul, Yogyakarta. Prosiding Seminar
Nasional Masyarakat Biodiversity Indonesia. 5 Agustus 2015.

Torrico, A.K., E.E. Cafrune, V.C. Conci. 2010. First report of Shallot latent virus on garlic in Argentina. Plant Dis. 97(7):915. DOI: http://dx.doi.org/10.1094/PDIS94-7- 0915B.

Wulandari, A.W., S.H. Hidayat, Sobir. 2015. Deteksi virus pada bawang merah (Allium cepa var. ascalonicum) dengan metode Dot Immuno Binding Assay. J. Hort. 14(4): 350-356.

Wulandari, A.W. 2016. Eliminasi virus dari umbi bawang merah dengan perlakuan air panas dan kultur jaringan. Tesis. Sekolah Pascasarjana Institut Pertanian Bogor. Bogor. 38 hal. 